Results of approbation of the program for the development of active imagination and its building in adolescents

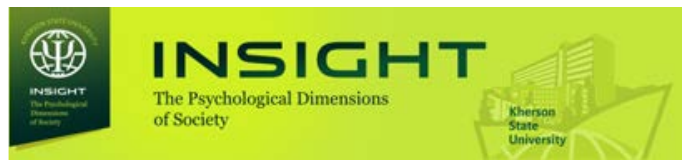

DOI: $10.32999 / 2663-970 X / 2021-5-5$

Link article (Style APA): Andrushko Ya. S. (2021). Assessment of subject's readiness for urgent actions using the variations of sensorimotor response tasks. Insight: the psychological dimensions of society, 5, 67-81. DOI: $10.32999 / 2663-970 X / 2021-5-5$

Link article (Style DSTU 8302: 2015): Andrushko Ya. S. Results of approbation of the program for the development of active imagination and its building in adolescents. Insight: the psychological dimensions of society, 2021, 5, 67-81. DOI: 10.32999/2663-970X/2021-5-5

UDC 159.954.2:37.015.31

\title{
Results of approbation of the program for the development of active imagination and its building in adolescents
}

\author{
Результати апробації програми розвитку активної уяви \\ та її побудови у підлітків
}

Received: May13, 2020

Accepted: May 25, 2021

\author{
Andrushko Yaryna Stepanivna, \\ $\mathrm{PhD}$ in Psychology, \\ Senior Lecturer of the Department \\ of Theoretical and Practical Psychology \\ Lviv Polytechnic National University \\ YarunaAn@hotmail.com \\ ORCID 0000-0003-1741-8625
}

\author{
Андрушко Ярина Степанівна, \\ кандидат психологічних наук, \\ доцент кафедри теоретичної \\ та практичної психології \\ Національний університет \\ “Львівська політехніка" \\ YarunaAn@hotmail.com \\ ORCID 0000-0003-1741-8625
}

\begin{abstract}
Active imagination is a kind of dialogue that a person conducts with different parts of "ego". The article has expressed the need to introduce a comprehensive program for the development of active imagination and its constellations in adolescents. The purpose of the article is to elaborate a model for imagination development, particularly active, in adolescents; to justify the comprehensive program for the development of adolescents' imagination at the psychological level using pedagogical methods and to approbate the comprehensive program in the educational space. Research methods: "The achievement motive" (modified by M. Mahomed-Eminova), "Diagnostics of personal creativity" (O. Tunik), "Diagnostics of non-verbal creativity" (a short form of the Torrance Test adapted by A. Voronina), "Diagnostics of linguistic-cognitive creativity" (T. Halkina, L. Aleksieieva). Results. Upon indicators of achievement motivation of adolescents,
\end{abstract}

\begin{abstract}
Анотація
Активна уява - це свого роду діалог, який проводить особистість з різними частинами власного “Я”. У статті розкрито необхідність впровадження комплексної програми розвитку активної уяви та ії консталяцій у підлітків. Мета дослідження: розробка моделі розвитку уяви, зокрема активної в представників підліткового віку; обгрунтування комплексної програми розвитку уяви підлітків на психологічному рівні з використанням педагогічних методів та апробація комплексної програми в освітньому просторі. Методи дослідження: “Мотивація досягнення" (модифікація М. Магомед-Емінова), “Діагностика особистісної креативності" (О. Тунік), “Діагностика невербальної креативності" (короткий варіант тесту Е. Торренса, адаптація А. Вороніна), “Діагностика мовленнєво-мисленнєвої креативності" (Т. Галкіної, Л. Алексєєвої). Результати. За показником мотивації досягнення в підлітків переважає мотивація
\end{abstract}


there is a prevalence of the motive to avoid failures that indicates their low self-esteem, a lack of confidence and organization etc. Most respondents have also shown average and below average levels of the development of non-verbal and verbal-cognitive creativity. The research has established that personal creativity is at the average development level, which is manifested in curiosity, the ability to imagine and complicity of thinking. An indicator of risk tolerance is at a low level given respondents' tender age and adolescent crisis. Underdeveloped creative component of active imagination leads to the loss of further productivity of an adolescent and his becoming as a whole. Conclusions. Indicators of the ascertaining stage of the study have confirmed the undeveloped active imagination of adolescents and its main constellations that prompts the implementation of the program of psychological influence on the development of imagination. Post-formative actions have proved the availability of positive dynamics in the development of active imagination and its main components at a statistically significant level. This is a key proof of the effectiveness of the author's comprehensive program that approves its introduction in the psychological and pedagogical process of interaction between adolescents and grown-ups.

Key words: imagination, active imagination, constellations of active imagination, program for development of active imagination

\section{Introduction}

The latest interpretation of the concept of "imagination" is reduced to its rendering as a process of producing images by an individual, which are based on background experience but the personality didn't perceive them directly. At the same time, imagination is a fundamental component of human creativity, which is practically realized in the results of activity. Moreover, imagination helps to overcome uncertain situations through the approbation of different behavioral models. Adolescence is the most sensitive period.

Imagination is the internal representations of a personality. Another interpretation of this concept has come down to its understanding as a method of cognition and expansion of consciousness which has long been used in various religions to treat people. Each scientist identifies, in his opinion, significant characteristics.

The better part of research studies consider imagination in the context of reflection уникнення невдач, а це засвідчує їх низьку самооцінку, невпевненість, неорганізованість тощо. Також у значної частини респондентів виявлено середній та нижчий за середній рівні розвитку невербальної та вербально-мислиннєвої креативності. Встановлено, що особистісна креативність перебуває на середньому рівні розвитку, що виражається в допитливості, здатності уявляти та складності мислення. Показник готовності ризикувати також перебуває на низькому рівні, зважаючи на юний вік оптантів та наявність підліткової кризи. А недостатньо розвинена творча складова активної уяви обумовлює зниження подальшої продуктивності молодої людини i iï подальшого становлення загалом. Висновки. Показники констатувального етапу дослідження засвідчили недостатній рівень розвитку активної уяви підлітків та їі провідних консталяцій, що слугувало причиною впровадження програми психологічного впливу на розвиток уяви загалом. Як засвідчили постформувальні заходи, наявність позитивної динаміки щодо розвитку активної уяви та їі провідних компонентів на статистично значущому рівні у представників експериментальної групи. Це $\epsilon$ головним доказом ефективності запропонованої нами комплексної програми і уможливлює її впровадження в психолого-педагогічний процес взаємодії між підлітками та дорослими.

Ключові слова: уява, активна уява, підліток, консталяції активної уяви, програма розвитку активної уяви.

\section{Вступ}

Найсучасніше трактування поняття "уява" зводиться до трактування ії як процесу створення індивідом образів, які будуються на попередньому досвіді людини, однак, які особистість безпосередньо не сприймала. Водночас уява виступає фундаментальним компонентом в творчості особистості, а в реальності реалізується в якості результатів діяльності. Окрім цього, уява допомагає долати ситуації невизначеного характеру, за допомогою апробації різних моделей поведінки. Найсензитивнішим періодом для розвитку уяви $\epsilon$ пубертатний.

Уява - це внутрішні уявлення особистості. Ще одне трактування цього поняття зводиться до розуміння його, як методу пізнання та розширення свідомості, який з давніх часів використовувався в різних релігіях для лікування людей. Кожен науковець виокремлює, на їхню думку, значущі характеристики.

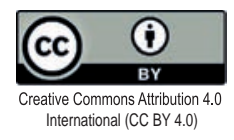


Results of approbation of the program for the development of active imagination and its building in adolescents

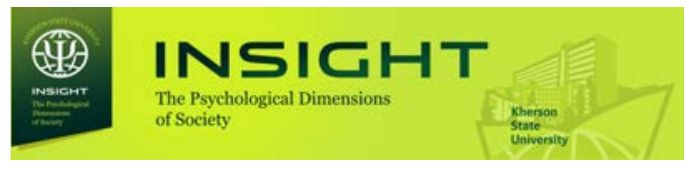

Уява, в більшості наукових розвідках, розуміється в контексті відображення навколишньої дійсності, створення нових образів тощо. Уяву від інших психічних пізнавальних процесів відрізняє наочний характер протікання. Пасивна та активна уява - це найпоширеніші різновиди уяви, оскільки саме ці види дозволяють відрізнити та надати міру свідомого та активного ставлення до реальності. Водночас пасивна уява поділяється на довільну та мимовільну, а активна уява - на творчу та відтворюючу. Проте не всі науковці поділяють таку думку.

Б. Дорст та Р. Фогель (2016) звертали увагу на дослідження Л. Веккера, який трактував уяву як наскрізний пізнавальний процес, який $\epsilon$ симетричний пам'яті, однак у протилежному напрямку. Також науковець виокремлює авторську класифікацію уяви. За основу в цій класифікації взято положення про особливості предметної психічної діяльності. Таким чином виокремлюється сенсорно-перцептивна уява або образна, яка поділяється на слухову, зорову, просторову, рухову тощо; словесно-логічна або концептуальна; оперативна уява як одна з можливих програм діяльності.

В американських наукових нейропсихологічних розвідках існують припущення, що основою сновидінь $\epsilon$ не психологічна, а виключно фізіологічна природа, оскільки при дослідженнях встановлено, швидкий рух очей засвідчує швидкий сон, що допомагає мозку опрацьовувати спогади. Проте новітні офтальмологічні дослідження припускають, що метою REM сну може бути оксигенація рогівки. Тобто $є$ зони мозку, які потребують подальшого детального експериментального вивчення (Kushner, 2016).

К. Г. Юнг (1952) розробив поняття “активна уява” у контексті вільного уявлення, як здатність розкриття внутрішніх образів індивіда в психотерапевтичному процесі. Саме в цьому випадку терапевт ніяк не впливає на ці процеси. Смислові імпульси власного "Я" індивіда будуть керувати цим процесом, але особистість має приймати те, що відбувається з нею. Зауважимо, що науковець використовував цей метод для дослідження себе. Отже, основним аспектом $\epsilon$ надання дозволу виникати approach to contact with gestalts and symbols. In 
opposition to other psychotherapeutic methods, active imagination is a method of spiritual selfenquiry and self-knowledge.

Before the XXth century the term "active imagination" outlined the approach to introspection and was being actively developed by B. Hannah and M. L. von Franz. During the life course, active imagination performs a series of functions which contribute to the activities of an individual, in particular: it sets an image-goal; allows predicting the results of human activity; provides reconstructing of the desired behavior in an awkward situation; maintains the producing of images which replace the work activity of the individual that he needs but is not possible objectively; allows one to fantasize, dream about things that seem unachievable in reality (Wallas, 2014). In this context, the essence of imagination is to increase and dip into consciousness, while expanding the boundaries of conscious immersion in images and the unconscious in general. Since an image allows one to reveal the area which was unknown, incomprehensible, vague, it becomes objectified. Moreover, the internal images usually appear during active imagination as effective images of active focus. This is particularly relevant under the framework of active imagination when it is necessary to be in an imaginary space.

Thus, imagination is closely associated with images. Besides, it is essential to take heed of the external world with its sounds and light, which also present in our imagination but are undeservedly ignored. The above forms of active imagination involve oral dialogues, i. e. the verbal function of the personality, which moves on to a new footing in comparison with observation, is activated.

Theoretical construct of the formative stage of this research is based on the provisions of analytical, systems, praxeological, dialogic, economic-psychological and personal approaches Altshuller, 2011; Savrasov, 2012; Hsu, Peng, Wang, Liang, 2014; Lewis, 2017; Woolley, Bunce, Boerger, 2020).

The systems approach is becoming widespread during the training of young people for future professional realization. This approach is considered as theoretical-practical, because every event, phenomenon, property or state is understood
3 несвідомого в свідомості. Активне уявлення схоже до медитативних технік, але їх відрізняє сукупність та взаємодія позиції пасивного спостерігача та активний підхід до вступу в контакт $з$ гештальтами та символами. Також на противагу іншим психотерапевтичним методам активне уявлення $\epsilon$ методом духовного самодослідження та самопізнання.

Термін “активна уява” ще до XX століття окреслював підхід до інтроспекції і активно розроблявся Б. Ханною та М.Р. фон Франц. В процесі життєдіяльності особистості активна уява виконує ряд функцій, що сприяють діяльності індивіда, зокрема:створює образ-мету;дозволяє прогнозувати результати активності людини; забезпечує програвання бажаної поведінки в незрозумілій ситуації; забезпечує продукування образів, що замінюють трудову активність індивіду, яка йому потрібна, однак об'єктивно $є$ не можливою; дозволяє фантазувати, мріяти про те, що в реальності здається неможливим (Wallas, 2014). Суть уяви в цьому контексті зводиться до збільшення та заглиблення в прошарку свідомості, при цьому розширюючи кордони свідомого занурення в образи та несвідоме загалом. Оскільки образ дозволяє розкрити ту ділянку, яка була невідомою, незрозумілою, розпливчастою, а зараз стала опредметненою. При цьому ті внутрішні образи звично з'являються в активному уявленні в якості дієвих образів, активного спрямування. Особливо це актуально при проведенні сеансу активного уявлення, де потрібно перебувати в уявному просторі.

Таким чином, уява тісно пов'язана з образами. Водночас не варто забувати про зовнішній світ, де $є$ звуки, світло, які також $є$ в нашій уяві, але незаслужено залишаються без уваги. Саме вищі форми активної уяви задіюють усні діалоги, тобто активізується вербальна функція особистості, яка стає на щабель вищою в порівнянні зі спостереженням.

Теоретичний конструкт нашого формувального етапу дослідження грунтується на положеннях аналітичного, системного, праксеологічного, діалогічного, економіко-психологічного та особистісного підходів (Альтшуллер, 2011; Саврасов, 2012; Hsu, Peng, Wang,

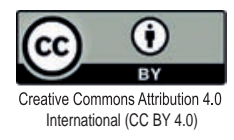


Results of approbation of the program for the development of active imagination and its building in adolescents as a system. Relying on the fundamentals of the systems approach, it has been elaborated the program for the development of active imagination of adolescents as an integral system which contributes to the personal development and becoming. In the context of the activity approach, the personality is regarded as an active individual, who is progressing through work and communication. A statement that a person is learning is the core of the research, and the basis is the motives for educational activities, personality traits, etc. Another substantial idea relates to the fact the personality is an active member of society, who is advancing in terms of the activity, communication, interpersonal realm. The dialogic approach is of significance while forming and identifying person-centered style of relations between a teacher and a student. Moreover, the teacher treats the student personality as imaginative nature, who can make great strides in the future. In the author's opinion, when developing imagination, particularly active, theoretical principles of the praxeological approach, which provides for purposeful preparation for work to achieve high performance and results, hold much significance.

One of the best-known theories of inventive problem solving by G. Altshuller (2011), as well as others, was designed to solve various creative tasks in the relevant activity. At present, it is wide-spread in humanities and business, since it allows a person to master specialized methods and techniques of the creative thinking.

The prominent Ukrainian scientist V. Moliako (2008) delt with the issues of creativity. He marked the following dominant technologies: combining, reconstructing, a universal strategy and a strategy of random substitutions.

The research by Black, J. E. and Barnes, J. L. (2019), who studied the influence of science fiction on imagination and creative processes of a person, seems interesting. The scientists established that an individual's active imagination and involvement in the events permit to develop unique ways of using this information. Another scientist Whitworth M. H. (2020) identified historicism of the concepts of "imagination" and "creativity" in a book by Tom McLeish through developing verbal and non-verbal mechanisms of the functioning of imagination.

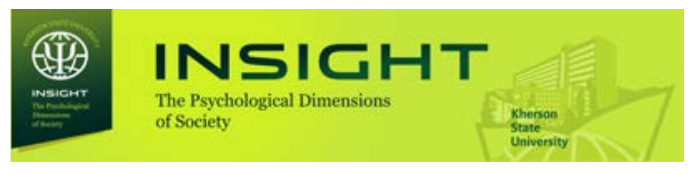

Liang, 2014; Lewis, 2017; Woolley,Bunce,Boerger, 2020).

Системний підхід набуває широкого розповсюдження в рамках навчання молодих людей для майбутньої професійної реалізації. Цей підхід розглядається, як теоретико-практичний, оскільки кожне явище, феномен, властивість чи стан розуміється, як система. Грунтуючись на засадах системного підходу було розроблено програму розвитку активної уяви підлітків як цілісної системи, що сприяє особистісному розвитку та становленню.У контексті діяльнісного підходу особистість розглядається, як діяльнісний індивід, що розвивається через роботу та комунікацію. В центрі дослідження $є$ положення про те, що людина навчається, а основою $€$ мотиви навчальної діяльності, індивідуальні властивості особистості тощо. Ще один вагомий постулат стосується того, що особистість активний учасник суспільства, який постійно розвивається в діяльності, спілкуванні, міжособистісній сфері. Вагомим є діалогічний підхід при формуванні та вияві особистісно орієнтованого стилю відносин між педагогом та учнем. При цьому вчитель бачить в особистості школяра творчу натуру, яка в подальшому може досягти неабияких успіхів. На нашу думку, у розвитку уяви, зокрема активної, важливе значення мають теоретичні постулати праксеологічного підходу, в якому передбачається цілеспрямована підготовка до роботи з метою досягнення високих показників та результатів.

Одна з найвідоміших теорій рішення винахідницьких завдань Г. Альтшуллера (2011) та інших була розроблена для вирішення різного роду творчих завдань у винахідницькій діяльності. На даний момент вона відома у гуманітарних науках та бізнесі, адже дозволяє людині оволодіти спеціальними техніками та технологіями творчого мислення.

Провідний український науковець В. Моляко (2008) досліджував проблеми творчості. Він виокремлював такі провідні стратегії конструювання: комбінування, реконструювання, універсальна стратегія та стратегія випадкових підстановок.

Цікавим видається дослідження Black, J. E. та Barnes, J. L. (2019), які досліджували вплив науково-фантастичної літератури на уяву 
The purpose of the research is to elaborate a model for the development of imagination, including active one, in adolescents; to justify the comprehensive program for the development of imagination of adolescents at the psychological level using pedagogical methods; to approbate the comprehensive program in the educational space.

\section{Methodology}

The empirical research was preceded by the definition of main constellations of active imagination, which could be identified at the empirical level. Thus, an intellectual-creative componentisformed dueto the cognitive-divergent thinking, namely, it characterizes adolescents as creative and inspired persons who strive to learn something new, discover new dimensions of life. Development of the motivational component is based on the achievement motivation, an adolescent's desire to attain success. As for the latter component - emotional-volitional - it comprises risk tolerance, identification of personal behavior in a risky situation (Muzyka, 2006; Savrasov, 2012; Collins, 1999).

The empirical research has involved four stages. It has been essential to conduct an expert assessment, which makes it possible to establish constellations of active imagination of adolescents, at the first research stage. The second stage has involved the substantiation of the methodological framework of the study and methodological support. The third stage has facilitated to determine peculiarities and dynamism of the active imagination of adolescents in its structural components (emotional-volitional, motivational, intellectual-creative and communicative). The fourth stage has called for the approbation of the comprehensive program for the development of active imagination of an adolescent.

The fundamental assumption of this research is an idea asserting that active imagination of an adolescent, as a dynamic formation, functions due to the harmonious development of emotional-volitional, motivational, intellectualcreative and communicative components, the identification of which is realized through psychological means during educational activities. Therefore, theoretical fundamentals afford ground та творчі процеси людини.Науковці встановили, що активне уявлення індивідом та залучення до подій дозволяє розкривати унікальні способи використання цієї інформації. Інший дослідник Whitworth М. Н. (2020), розкрив історизм понять “уява" та “творчість" у книзі Тома Макліша, та розкриваються вербальні та невербальні механізми функціонування уяви.

Метою дослідження було розробити модель розвитку уяви, зокрема активної, в представників підліткового віку; обгрунтувати комплексну програму розвитку уяви підлітків на психологічному рівні з використанням педагогічних методів, та апробація комплексної програми в освітньому просторі.

\section{Методологія}

Емпіричному дослідженню передувало визначення провідних консталяцій активної уяви, які можна було б визначити на емпіричному рівні. Так інтелектуально-творчий компонент формується завдяки когнітивно-дивергентному мисленню, тобто це характеризує підлітків як творчих та натхненних особистостей, що прагнуть пізнавати нове, відкривати нові грані життя. Мотиваційний компонент за основу свого розвитку має мотивацію досягнення, орієнтацію підлітка на досягнення успіху. Щодо останнього компоненту - емоційно-вольового, то його підгрунтям $є$ готовність ризикувати, виокремлення індивідуального стилю поведінки в ризиковій ситуації (Музика, 2006; Саврасов, 2012; Collins, 1999).

Емпіричне дослідження відбувалось в чотири етапи. Отже, на першому етапі дослідження необхідно провести експертну оцінку, яка дозволить визначити консталяції активної уяви в підлітків. Другий етап передбачав обгрунтування методологічної бази дослідження та методичного забезпечення. Третій етап допоміг встановити особливості та динамічність активної уяви підлітків в їі структурних компонентах (емоційно-вольовому, мотиваційному, інтелектуально-творчому та комунікативному). Четвертий етап передбачав апробацію комплексної програми щодо розвитку активної уяви особистості пубертата.

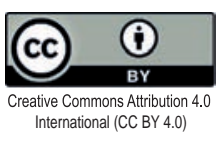




\section{Results of approbation of the program for the development of active imagination and its building in adolescents}

to present the author's model for the development of active imagination and its constellations (fig. 1).

Theoretical and methodological analysis confirms that it is essential to adhere to some psychological and pedagogical conditions for the development of imagination to implement the program:

- to use an individual approach in the organization of learning activities of adolescent students;

- to apply active methods of teaching and triggering the cognitive activity of adolescents (heuristic and divergent);

- to do the groundwork for activating the creative potential of the adolescent personality.

Separation of these conditions permits the young generation of adolescents to develop their imagination and creative potential. According to L. Petryshyna and R. Shvai (2014), creative space is a basis for the development of imagination of the adolescent personality. In addition, psychological and pedagogical characteristics and patterns of the functioning of imagination and active imagination, which is maintained by creative learning activity of adolescents, are considered.
Фундаментальним припущенням нашого дослідження виступає твердження про те, що активна уява підлітка, як динамічне утворення функціонує завдяки гармонійному розвитку емоційно-вольового, мотиваційного, інтелектуально-творчого та комунікативного компонентів, вияву яких сприятимуть психологічні засоби під час навчальної діяльності. Отже, теоретичні засади дають підстави для представлення авторської моделі розвитку активної уяви та її консталяцій (рис. 1).

Теоретико-методологічне аналізування засвідчує, що для реалізації цієї програми необхідно дотримуватись певних психологічних та педагогічних умов розвитку уяви:

- використання індивідуального підходу в організації навчальної діяльності школярів-підлітків;

- застосування активних методів навчання та активізації пізнавальної діяльності пубертатів (еврестичного та дивергентного характеру);

- створення сприятливих умов для активізації творчого потенціалу особистості підлітка.

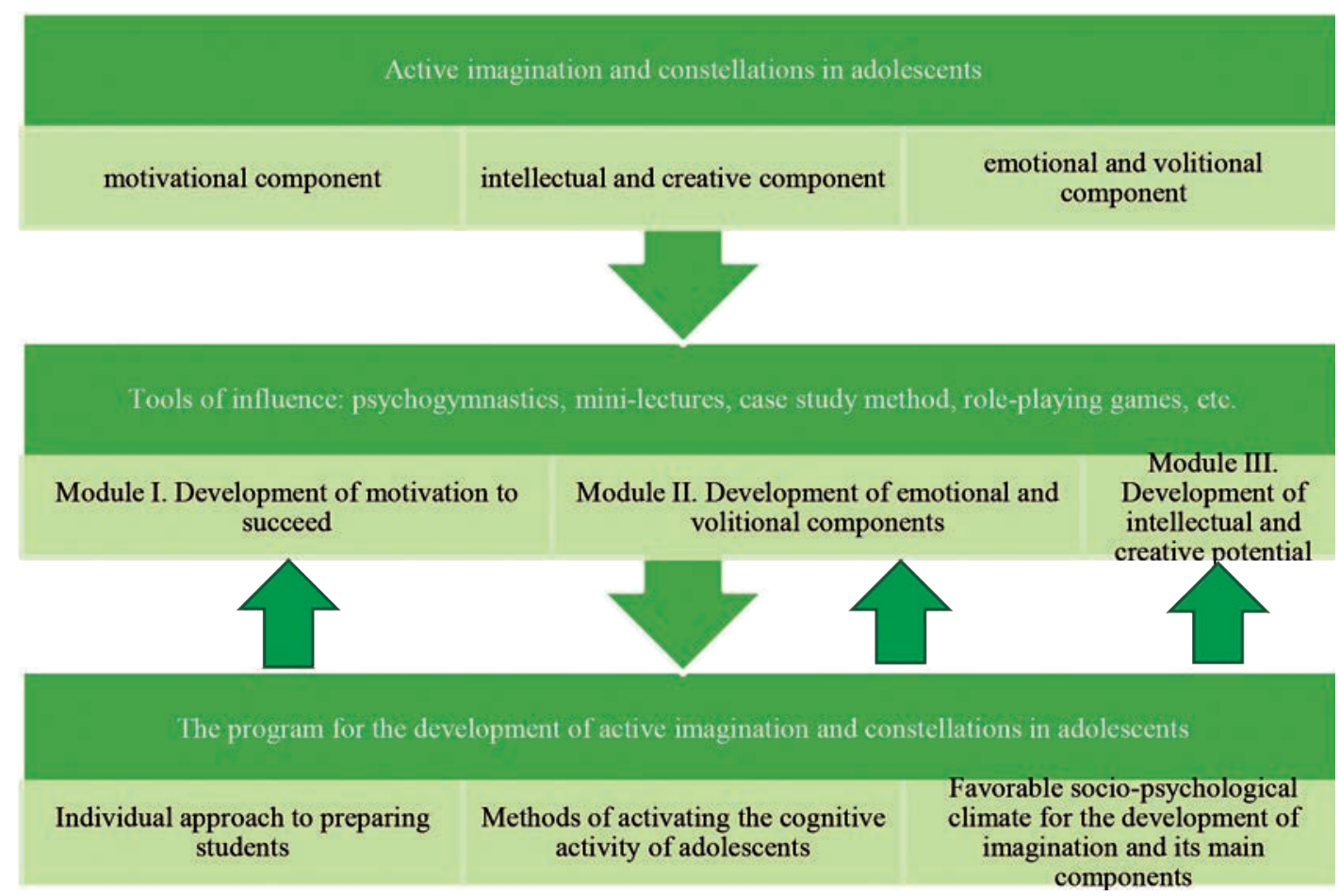

Fig. 1. The author's model for the development of active imagination and its constellations in adolescents

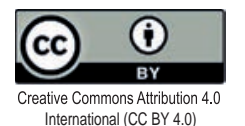




\section{Results}

To check the effectiveness of the developed andapprobated comprehensive program, theauthor has undertaken a research of formative nature. An experimental group (100 persons) and a control group (100 persons) have been re-evaluated using the methods from the ascertaining stage of the study. To check the statistical significance of the research results of every program component before and after the formative experiment, the descriptive statistics have been used.

Comparison of the results before and after the formative experiment indicates significant changes in the indicators of failure avoidance and achievement motivation in the experimental group. Thus, achievement motivation increased from $27.6 \%$ to $44.8 \%$, and the motive to avoid failures decreased from $72.4 \%$ to $55.2 \%$. The author explains the above by moral-psychological stimulation of adolescents during the experiment through praising and verbal encouragement.

There are research results in terms of nonverbal creativity, linguistic-cognitive creativity, imagination and curiosity. Analysis of the research proves the positive changes in the qualitative and quantitative indicators of the respondents after the approbation of the comprehensive program. In particular, the indicators of the high level increased from $6.9 \%$ to $10.3 \%$, as well as of above average - from $13.8 \%$ to $24.1 \%$ and average - from $41.4 \%$ to $48.3 \%$. It is observed the decrease of data of the below average level from $24.1 \%$ to $13.8 \%$ and low level - from $13.8 \%$ to $3.5 \%$. It means the respondents who have felt under experimental influence are prone to change their stereotypical perception of thinking, which is expressed in the transformation of the real world in a new way. This positively influences the further personal becoming of an adolescent.

Another essential component of this research includes the development of intellectual and creative constellation, which comprises an indicator of originality and uniqueness. Therefore, the originality indicator established the following changes in the experimental group: the level of verbal creativity increased from 3.5\% to $10.3 \%$; the above average level increased from $10.3 \%$ to $17.2 \%$; at the average level, the development of verbal creativity increased
Виокремлення цих умов дає можливість молодому поколінню підлітків розвивати свою уяву та творчий потенціал. На думку Л. Петришина та Р. Швай(2014), креативний простір є фундаментом для розвитку уяви особистості підлітка, а при цьому враховуються психолого-педагогічні характеристики та закономірності функціонування уяви та активної уяви, що забезпечується творчою навчальною діяльністю підлітків.

\section{Результати}

Для того щоб перевірити ефективність розробленої та апробованої нами комплексної програми, було проведено дослідження формувального характеру. Експериментальна група (100 осіб) та контрольна група (100 осіб) були повторно досліджені методиками з констатувального етапу дослідження. Щоб перевірити статистичну значущість результатів дослідження кожного компоненту програми до та після формувального експерименту, було застосовано методи дискрептивної статистики.

Порівняння результатів до та після формувального експерименту вказує на суттєві зміни за показниками уникнення невдач та мотивації досягнення успіху в експериментальній групі. Так показник мотивації прагнення до успіху збільшився з $27.6 \%$ до $44.8 \%$, а показник мотивації уникнення невдач зменшився з 72.4 \% до 55.2 \%.Пояснюємо це індивідуально морально-психологічною стимуляцією підлітків під час проходження експерименту, використовуючи похвалу та вербальне заохочення.

Розглянемо результати дослідження за показниками невербальної креативності/ творчості, мовленнєво-мисленнєвої креативності, уяви та допитливості.Аналізування результатів засвідчує позитивні зміни в якісних та кількісних показниках респондентів після апробації комплексної програми. Зокрема, зросли показники високого рівня з 6.9 \% до $10.3 \%$, а також вище середнього з $13.8 \%$ до $24.1 \%$ та середнього - $341.4 \%$ до $48.3 \%$. Виявлено зниження даних рівня нижче середнього з 24,1\% до 13.8 \% та низького рівня - з 13.8 \% до $3.5 \%$. Тобто ті оптанти, що

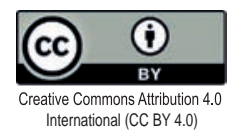




\section{Results of approbation of the program for the development of active imagination and its building in adolescents}

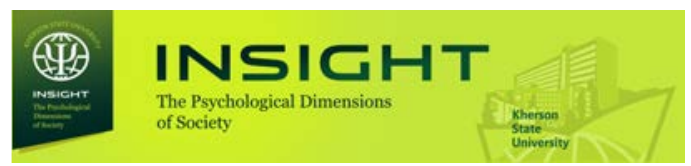

проходили експериментальний вплив, все ж схильні до зміни свого стереотипного сприйняття мислення, що виражається в перетворенні навколишньої дійсності по-новому. Це позитивно впливає на подальше становлення особистості підлітка.

Ще одним вагомим компонентом нашого дослідження було розвиток інтелектуально-творчої консталяції, до якої входить показник оригінальності та унікальності. Отже, за показником оригінальності встановлено в експериментальній групі такі зміни: рівень вербальної креативності збільшився з 3,5 \% до 10,3 \%; рівень вищий за середній збільшився з 10,3 \% до 17,2 \%; за середнім рівнем розвиток вербальної креативності збільшився з 48,3 \% до 55,2 \%; зменшилися показники рівня нижче середнього з 27,6 до 13,8 \%; низького рівня - $з$ 10,3 до 3,5 \%.

Проаналізуємо результати за індексом унікальності в контрольній та експериментальній групах до та після експерименту. Показники високого рівня зросли з 3,5 \% до 10,3 \%, рівень вищий за середній зріс з 13,8 \%

\section{Активна уява та їі консталяції в підлітків}

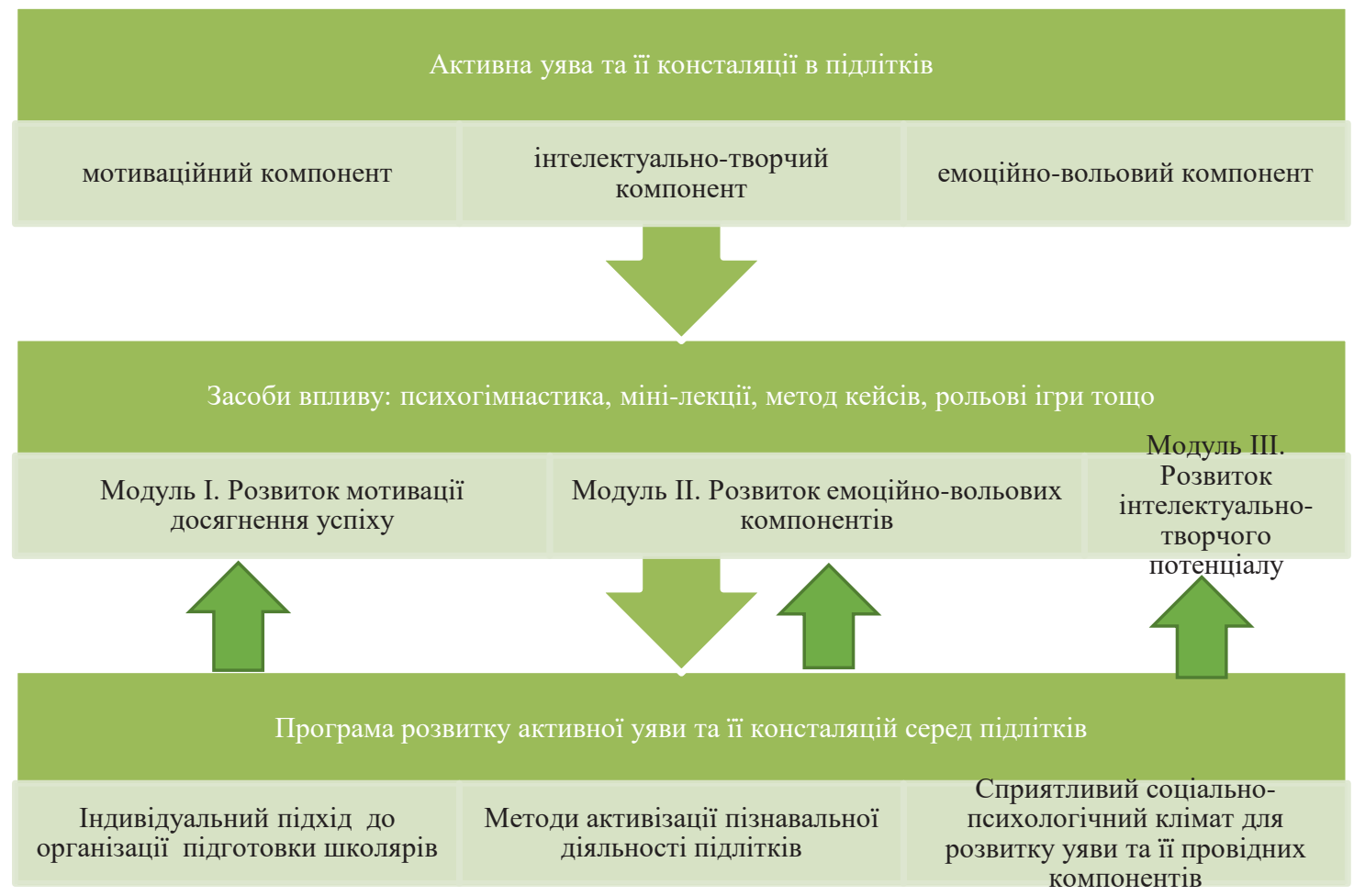

Рис. 1. Авторська модель розвитку активної уяви та її консталяцій в підлітків

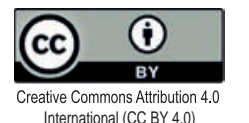


of development of these characteristics in adolescents before and after the experiment. In terms of curiosity, the experimental group showed the following changes: the high level of curiosity increased from $10.3 \%$ to $13.8 \%$; the higher level raised from $20.7 \%$ to $24.1 \%$; the average level increased from $44.8 \%$ to $51.7 \%$. At the same time, indicators of the lowered level decreased from $13.9 \%$ to $6.9 \%$, and low level - from $10.3 \%$ to $3.5 \%$. The control group demonstrated insufficient changes at the average level (by 3.5\%) of the curiosity indicator due to the lowered level. The formative influence on the adolescents helped to change the attitude of high school students to the learning of different sorts of things and extended horizons for the creative solution of various situations.

The development level of adolescents' imagination was analyzed as well. The dynamics of the results show the following changes in the experimental group of respondents: the high level increased from $3.5 \%$ to $10.3 \%$; the higher level - from $17.2 \%$ to $24.1 \%$, and the average - from $37.9 \%$ to $48.3 \%$; the indicators of the lower level decreased from $27.6 \%$ to $13.8 \%$ and of the low level - from $13.8 \%$ to $3.5 \%$. The dynamic changes were not fixed in the control group. Thus, the results confirm growth in the development level of imagination (particularly active) and creativity in adolescents that has definitively positive effect on the further intensive development of puberty. Moreover, this is a significant progress in the personal growth, because it shows that Ukrainian society has a very creative young generation that needs support and encouragement in their endeavors.

Thelastimportantcomponent of theintellectual and creative constellation of active imagination is the complexity of thinking. The formative experiment confirmed pleasant changes under all the indicators of the experimental group, as follows: the high level increased from 3.5\% to $10.3 \%$; the higher level - from $13.8 \%$ to $20.7 \%$; average - from $44.8 \%$ to $55.2 \%$; indicators of the lower level decreased from $20.7 \%$ to $10.3 \%$ and of low - from $17.2 \%$ to $3.5 \%$. Sweeping changes were not noticed in the control group. In adolescence, it is essential to give an individual freedom to develop perseverance, independence до $24,1 \%$, середній рівень - 3 41,3 \% до 48,3 \%, рівень нижчий за середній зменшився з 27,6 \% до 13,8 \%, а низький - 313,8 \% до 3,5 \%. Щодо контрольної групи, то суттєвих змін не встановлено.Підлітки під час виконання цих завдань, які вимагали неординарності мислення, проявили весь спектр творчості та активізували уяву, а це сприяло здатності висувати оригінальні та унікальні ідеї на вербальному рівні. В дорослому віці це дозволить розкрити творчий потенціал людини в неординарних професіях.

Пубертатний період розвитку особистості характеризується активізацією допитливості як індивідуальної властивості та уяви з іiі складовими, що взаємодіють 3 мислиннєвою сферою. За методикою “Діагностика особистісної креативності" було встановлено міру розвитку цих характеристик у підлітків до та після експерименту.В експериментальній групі за показником допитливості з'ясовано такі зміни: високий рівень допитливості збільшився з 10.3 \% до 13.8 \%; підвищений з $20.7 \%$ зріс до $24.1 \%$; середній рівень зріс з 44.8 \% до $51.7 \%$. Водночас зменшилися показники із заниженого рівня з 13,9 \% до 6,9 \% та низького рівня - з $10.3 \%$ до $3.5 \%$. А у контрольній групі виявлено несуттєві зміни в середньому рівні (на $3,5 \%$ ) розвитку показника допитливості за рахунок заниженого рівня. Формувальний вплив на підлітків допоміг змінити ставлення старших школярів до пізнання нового та розширив горизонти творчого вирішення різних ситуацій.

Далі проаналізуємо рівень розвитку уяви підлітків. Динаміка результатів засвідчує такі зміни в експериментальній групі респондентів: високий рівень збільшився з $3.5 \%$ до 10.3 \%; підвищений рівень - $317.2 \%$ до $24.1 \%$ та середній - $337.9 \%$ до 48.3\%; знизилися показники заниженого рівня з $27.6 \%$ до $13.8 \%$ та низького - з 13.8 \% до 3.5\%. У контрольній групі динамічних змін не зафіксовано. Отже, ці результати засвідчують зростання рівня розвитку уяви (активної зокрема) та творчості в підлітків, а це однозначно позитивно впливає на подальший інтенсивний розвиток пубертата. Окрім того, це значний прогрес в індивідуальному розвитку, адже засвідчує 
Results of approbation of the program for the development of active imagination and its building in adolescents

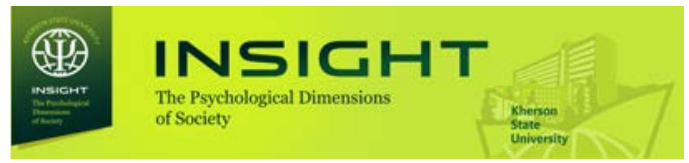

and responsibility for his actions. Thus, adults effectively stimulate proper and positive processes on course to solving complex real-life problems.

Emotional and volitional constellation of active imagination is rendered by the indicators of risk tolerance. It worth noting that the indicators of adolescents' readiness gained in the experimental group, as follows: high level indicators increased from $3.5 \%$ to $10.3 \%$; the higher level - from $13.8 \%$ to $20.7 \%$; average from $48.2 \%$ to $55.2 \%$. The decrease was observed at the lower and low level - from $20.7 \%$ to $10.3 \%$ and from $17.2 \%$ to $3.5 \%$ respectively. These data mark a positive impact of the comprehensive program as adolescents from the experimental group showed a desire to express their position and confidence in defending their opinions, new ideas etc.

According to the results of comparative analysis, differences in the above indicators after the introduction of the comprehensive program for the development of active imagination in adolescents were established. In particular, differences were found out upon the achievement motivation scale $(\mathrm{t}=3.52, \mathrm{p}<.000)$. The author associates the increase in this indicator with use in the comprehensive program of mediumcomplexity tasks, the implementation of which required the optimal amount of effort. The active imagination scale differs by the results before the introduction of the program and after its approbation $(\mathrm{t}=2.20, \mathrm{p}<.05)$. In the author's opinion, this fact relates to development mechanisms of heuristic and divergent thinking, sensitivity of adolescence for its prosperity. The curiosity scale also differed $(\mathrm{t}=3.42$, $\mathrm{p}<.001)$. Adolescence is a period of knowing oneself, one's inner world, self-understanding, an incentive to step out of one's comfort zone. Another difference was found under the scale of linguistic-cognitive creativity (uniqueness) $(\mathrm{t}=3.02, \mathrm{p}<.005)$. This proves the activation of the mechanisms of creative thinking, which are caused by emotional experiences at this age and are a reflection of the internal (mental) activity of an adolescent. Sweeping statistically significant changes in the results of the respondents from the experimental group are established. This confirms the effectiveness and expediency те, що в українському суспільстві надзвичайно творче молоде покоління, яке потребує підтримки та стимулювання в своїх починаннях.

Останнім важливим компонентом інтелектуально-творчої консталяції активної уяви $\epsilon$ складність мислення. Формувальний експеримент засвідчив позитивні зміни за всіма показниками в експериментальній групі, зокрема: високий рівень збільшився з 3,5\% до 10,3 \%; підвищений рівень - 3 13,8 \% до $20,7 \%$; середній - $344,8 \%$ до 55,2 \%; знизилися показники заниженого рівня з 20,7 \% до 10,3 \% та низького - 3 17,2 \% до 3,5 \%. Суттєвих зрушень в контрольній групі не виявлено.У підлітковому віці важливо надавати свободу особистості аби сформувати наполегливість, самостійність та відповідальність за свої дії. Отож, дорослі ефективно активізують правильні та позитивні процеси на шляху до розв'язання складних життєвих завдань.

Емоційно-вольова консталяція активної уяви представлена показником готовності до ризику. Варто зазначити, що в експериментальній групі збільшилися показники за рівнями готовності підлітків, зокрема: показники високого рівня зросли з 3,5\%до 10,3\%; підвищеного - $з$ 13,8\% до 20,7 \%; середнього з 48,2 \% до 55,2 \%. Зниження ж відбулось за заниженим та низьким рівнем з 20,7 \% до 10,3 \% та з 17,2 \% до 3,5 \%. Ці дані вказують на позитивний вплив комплексної програми, оскільки підлітки з експериментальної групи проявили бажання висловлювати свою позицію та впевненість у відстоюванні своєї думки, нових ідей тощо.

За результатами порівняльного аналізування встановлено відмінності у запропонованих показниках після впровадження комплексної програми розвитку активної уяви в підлітків. Зокрема, відмінності встановлено за шкалою "мотивація досягнення успіху" $(\mathrm{t}=3.52$, $\mathrm{p}<.000)$. Ми пов'язуємо зростання цього показника із застосуванням у комплексній програмі завдань середньої складності, виконання яких потребувало оптимальної кількості зусиль. Шкала “активна уява"відрізняютьсярезультатами до впровадження програми та після ії апробації ( $\mathrm{t}=2.20, \mathrm{p}<.05)$. Вважаємо, що це пов'язано 3 механізмами розвитку еврестичного

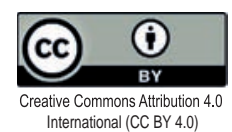


of the formative influence.

\section{Discussion}

Active imagination is a special concept and method in psychological science proposed by C. G. Jung (1952) to describe images of a personality during a therapeutic session. In such a way, a person seeks to have access to information that is not available yet. The scientist conveyed active imagination as "finality". Active imagination comprises a set of fantasies which are stimulated through evenly suspended attention. Symbols, images, fantasies are a body of active imagination. Peculiarities of active imagination make it original. The development of imagination, active imagination is brighter depending on age, interests and needs of the personality, emotionality and dynamism. The very human needs are an incentive to create new images etc.

Active imagination requires in-depth reflection. Active imagination is not an essential component of the development of an adolescent. In adolescence, it becomes a way of mastering the purposeful nature of the human being. A potential of changes origins intrinsically, because the development and changes are peculiar to a person at the level of archetypes. Thus, a person uses this resource. Capabilities of active imagination are not pronounced within one age range. This capability develops and remains for life - from childhood to old age.

L. Drozd and Yu. Bystrova (2020) state in their research that it is essential to form conscious understanding of cognitive-linguistic processes for effective socialization of adolescents that allow mastering soft skills which determine the creative potential of a man. At the same time, I. H. Radul, O. V. Hundarenko and M. M. Kowalczyk (2020) write that egotism of a student reflects "ego" of the person and actualizes the desire to present oneself to society by using a set of creative tools. In studying the processes of imagination and creativity of an individual, researchers W. Jing-Jyi and D. L. Albanese (2013) place special emphasis on the introduction of creativity in academic programs in all educational institutions which, in their opinion, is the basis for child's personality development. These studies highlight the importance of implementing the program for та дивергентного мислення, сензитивності підліткового віку для іiї розквіту. Наступною шкалою, за якою встановлено відмінність "допитливість" ( $\mathrm{t}=3.42, \mathrm{p}<.001)$. Підлітковий вік - це період пізнання себе, свого внутрішнього світу, саморозуміння, стимул до виходу із зону комфорту. Ще одну відмінність з'ясованоо за шкалою "мовленнєво-мисленнєва креативність (унікальність)” ( $\mathrm{t}=3.02, \mathrm{p}<.005)$.Це засвідчує активізацію механізмів творчого мислення, які зумовлені емоційними переживаннями в цьому віці та $\epsilon$ відображенням внутрішньої (ментальної) активності підлітка.Встановлено, що $€$ суттєві статистично вагомі зміни в результатах респондентів з експериментальної групи. А це засвідчує результативність та доцільність формувального впливу.

\section{Дискусія}

Активнауява $є$ особливимпоняттям та методом в психологічній науці, що запропонував К. Г. Юнг (1952) аби описати уявлення особистості під час терапевтичного сеансу. Тобто, таким чином людина прагне отримати доступ до тієї інформації, яка поки недоступна. Вчений називав активну уяву поняттям "фінальності". Активна уява містить сукупність фантазій, які викликаються за допомогою довільної концентрації. Символи, образи, фантазії становлять консистенцію активної уяви. Індивідуальні властивості активної уяви надають їй своєрідності. Розвиток уяви, активної уяви буде яскравішим в залежності від віку, інтересів та потреб особистості, емоційності та динамічності. Саме людські потреби виступають стимулом для творення нових образів тощо.

Активна уява потребує рефлексії на глибинному рівні. Активна уява не $\epsilon$ важливою складовою в розвитку підлітка, однак в дорослому віці стає шляхом до опанування цілеспрямованості в людському бутті. Потенціал змін виникає сам по собі, оскільки розвиток та зміни закладені в людині на рівні архетипів. I людина використовує цей потенціал. Можливості активної уяви не є яскраво виражені лише в одному віковому діапазоні. Ця можливість розвивається та залишається на все життя - від дитинства до старості.

У своїх дослідженнях Дрозд Л. та Бистрова Ю. 
Results of approbation of the program for the development of active imagination and its building in adolescents the development of active imagination and its constellations in educational institutions.

Summarizing the findings of this theoreticalempirical research, the author emphasizes imagination is a mental process that combines the components determining creative potential of an individual which is realized in activities through psychological protection mechanisms. In the context of the present research, this structure consists of intellectual-creative, emotionalvolitional and motivation components.

\section{Conclusions}

The proposed model of active imagination of an adolescent involves motivational, emotional-volitional and intellectual-creative components. The author attributes an individual approach in educational activities, creation of a pleasant and comfortable climate for the development of creativity, the use of interactive and psychological methods of intercommunication with adolescents (games, heuristic techniques, training technologies, etc.) to the psychological conditions for the development of active imagination of an adolescent. Active imagination contains constellations which have peculiar criteria and indicators towards every component. The criterion for the development of intellectual and creative constellation implies maturity of the mental sphere upon the following indicators: curiosity, imagination, complexity of thinking, nonverbal and verbal-mental creativity. The criterion for the development of motivational constellation implies the achievement motivation and an indicator of obtaining success. The criterion for the development of emotional-volitional constellation is risk tolerance, and indicators - risk tolerance when rendering decisions of different sort of complexity.

It is worthwhile noting that the structural and semantic content of the comprehensive program has contributed to adolescents' formation of not only theoretical ideas about active imagination and its components but also the practical foundations of their development. Post-formative measures confirm positive dynamics in the advancement of active imagination and its main components at a statistically significant level in the experimental group. This

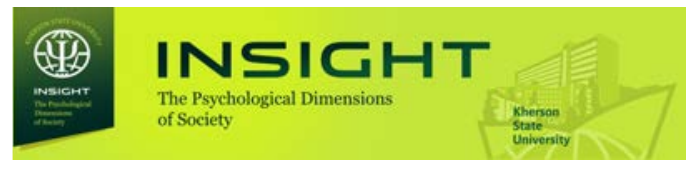

(2020) визначають, що для ефективної соціалізації підлітків потрібно формувати свідоме розуміння мисленнєво-мовних процесів, що дозволить оволодіти м'якими навиками, які зумовлюють творчий потенціал людини.Водночас у своїх наукових розвідках I. H. Radul, O. V. Hundarenko та M. M. Kowalczyk (2020) зауважують, що еготизм особистості школяра відображає власне "Я" особистості та актуалізує прагнення презентувати себе соціуму, використовуючи арсенал творчих інструментів.Дослідники W.Jing-JyiтаD. L. Albanese(2013), при вивченні процесів уяви та творчості особистості, особливий акцент робиться на впровадженні творчості у навчальних програмах у всіх освітніх закладах, що на їхню думку є основою для розвитку особистості дитини. Ці дослідження підтверджують важливість впровадження програми розвитку активної уяви та її консталяцій в освітніх установах.

Резюмуючи результати нашого теоретикоемпіричного дослідження, уява є психічним процесом, який поєднує складові, що визначають творчий характер індивіда, який розкривається в діяльності за допомогою психологічних механізмів захисту. У нашому дослідженні цю структуру становлять: інтелектуально-творчий, емоційно-вольовий та мотиваційний компоненти.

\section{Висновки}

Запропонована модель активної уяви підлітка містить мотиваційний, емоційно-вольовий та інтелектуально-творчий компоненти. До психологічних умов розвитку активної уяви підлітка зараховуємо індивідуальний підхід в навчальній діяльності, створення приємного та комфортного клімату для розвитку творчості, використання інтерактивних та психологічних методів взаємодії з підлітками (ігри, еврестичні прийоми, тренінгові технології тощо). Активна уява містить консталяції, які мають свої критерії та показники відповідно до кожного компонента. Критерієм розвитку інтелектуально-творчої консталяції встановлено сформованість мисленнєвої сфери за показниками: допитливість, уява, складність мислення, невербальна

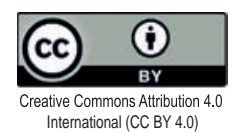


is key proof of the effectiveness of the author's comprehensive program that approves its introduction in the psychological and pedagogical process of interaction between adolescents and grown-ups.

The prospect of the further research involves clarifying key psychological mechanisms of the development of active imagination during psychotherapeutic session.

\section{References}

Altshuller, G. (2011). Find an Idea: Introduction to TIPS - Theory of Inventive Problem Solving. Moscow: Alpina Publishers.

Black, J. E., \& Barnes, J. L. (2019). Pushing the boundaries of reality: Science fiction, creativity, and the moral imagination. Psychology of Aesthetics, Creativity, and the Arts. Advance online publication. https:// doi.org/10.1037/aca0000281

Collins, M. A., Amabile, T. M. (1999) Motivation and creativity. Handbook of Creativity. R. Sternberg. Cambridge. 297-313.

Dorst, B., Fogel. (2016). Active imagination. Jungian approach. Kharkiv: Humanitarian Center.

Drozd, L. V., \& Bystrova, Yu. bO. (2020). Features of communication of adolescents with intellectual disabilities in the interpersonal relations. Insight: the psychological dimensions of society, 3, 123-133. DOI: 10.32999/2663-970X/2020-3-9

Hsu, Y., Peng, Li-Pei, Wang, Jiun-Hao \& Liang, C. (2014). Revising the Imaginative Capability and Creative Capability Scales: Testing the Relationship between Imagination and Creativity among Agriculture Students. International Journal of Learning, Teaching and Educational Research, 6, 1, 23-32.

Jung, C. (1952). Symbols of transformation. Zurich: Rascher Verlag.

Kushner, Dale M. (2016). Understand Your Dreams by Using Jung's "Active Imagination". Psychology Today. Retrieved from: https://www.psychologytoday. com/us/blog/transcending-the-past/201610/ understand-your-dreams-using-jungs-active-imagination

Lewis, P. (2017). Shackle on choice, imagination and creativity: Hayekian foundations. Cambridge Journal of Economics, 41(1), 1-24, https://doi. org $/ 10.1093 /$ cje/bew037

Muzyka, 0. 0. (2006). Muzyka 0. O. Social status and affiliation at the motivation of creative activity. Theoretical and methodical bases of education of the creative personality in the conditions of out-of-school educational institutions: coll. materials scientific-practical. conf. Kyiv: Gramota. S. $116-121$. та вербально-мисленнєва креативність. Критерієм розвитку мотиваційної консталяції встановлено мотивацію досягнення 3 показником досягнення успіху. Критерієм розвитку емоційно-вольової консталяції $\epsilon$ готовність ризикувати, а показниками - готовність ризикувати при прийнятті рішень різної складності.

Важливо зауважити, що структурна та змістова наповненість комплексної програми забезпечила формування в підлітків не лише теоретичних уявлень про активну уяву та її компоненти, а й практичні основи їх розвитку. Постформувальні заходи засвідчують позитивну динаміку щодо розвитку активної уяви та її провідних компонентів на статистично значимому рівні у представників експериментальної групи. Це є головним доказом ефективності запропонованої нами комплексної програми та уможливлює ії впровадження в психолого-педагогічний процес взаємодії між підлітками та дорослими.

Перспективу нашого дослідження вбачаємо у з'ясуванні ключових психологічних механізмів розвитку активної уяви під час психотерапевтичної взаємодії.

\section{Список використаних джерел}

Альтшуллер Г. Найти идею: Введение в ТРИЗ - теория решения изобретательских задач. Москва: АльпинаПаблишерз, 2011, 400 с.

Дорст Б., Фогель. Активное воображение. Юнгианский подход. Харків: Гуманитарный Центр, 2016, 200 с.

Музика 0. О. Соціальний статус та афіліація у мотивації творчої активності. Теоретикометодичні основи виховання творчої особистості в умовах позашкільних навчальних закладів: зб. матеріалів наук.-практ. конф. Київ: Грамота, 2006. Ч. 2. 2006. С. 116-121.

Саврасов М. В. Емоційно-мотиваційні складові креативності особистості: автореф. дис. на здобуття наук. ступеня канд. психол. наук: 19.00.01. Харків, 2012.18 с.

Стратегії творчої діяльності: школа В. О. Моляко. За заг. ред. В. О. Моляко. Київ: Освіта України, 2008, 702 c.

Швай Р. Психологія та педагогіка творчості. Львів: Видавництво Львівської політехніки, 2014. $200 \mathrm{c}$.

Black, J. E., \& Barnes, J. L. (2019). Pushing the boundaries of reality: Science fiction, creativity, 


\section{Results of approbation of the program for the development of active imagination and its building in adolescents}

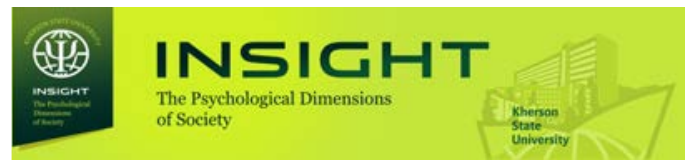

and the moral imagination. Psychology of Aesthetics, Creativity, and the Arts. Advance online publication. https://doi.org/10.1037/aca0000281

Collins, M.A., Amabile, T.M. (1999) Motivation and creativity. Handbook of Creativity. R. Sternberg. Cambridge. P. 297-313.

Drozd, L. V., \& Bystrova, Yu. O. (2020). Features of communication of adolescents with intellectual disabilities in the interpersonal relations. Insight: the psychological dimensions of society, № 3, P. 123-133. DOI: 10.32999/2663-970X/2020-3-9

Jung C. (1952). Symbols of transformation. Zurich: Rascher Verlag.

Kushner, Dale M. (2016). Understand Your Dreams by Using Jung's "Active Imagination". Psychology Today. Retrieved from: URL:https://www.psychologytoday.com/us / blog/transcending-the-past/201610/understand-your-dreams-using-jungs-active-imagination

Lewis, P. (2017). Shackle on choice, imagination and creativity: Hayekian foundations. Cambridge Journal of Economics, № 41(1), P. 1-24, https://doi. org/10.1093/cje/bew037

Radul I. H., Hundarenko O. V.,\& Kowalczyk M. M. (2020). Research of features of manifestation of junior schoolchild's egotism in communication with peers. Insight: the psychological dimensions of society, № 4, P. 73-89. DOI: 10.32999/2663-970X/ 2020-4-5

Wallas, G.(2014). The Art of Thought. Kent : Solis Press.

Wu, Jing-Jyi, Albanese, D. L. (2013). Imagination and creativity: wellsprings and streams of education the Taiwan experience. Educational Psychology. An International Journal of Experimental Educational Psychology, № 33(5), P. 20-23.https://doi.org/10.1 080/01443410.2013.813689

Hsu, Y., Peng, Li-Pei, Wang, Jiun-Hao, Liang, C. (2014). Revising the Imaginative Capability and Creative Capability Scales: Testing the Relationship between Imagination and Creativity among Agriculture Students. International Journal of Learning, Teaching and Educational Research, №6, P. 23-32.

Whitworth, M. H. (2020) The historicity of 'imagination' and 'creativity': a response to Tom McLeish's The Poetry and Music of Science (2019), Interdisciplinary Science Reviews, № 45(1), P. 8-15. DOI: 10.1080/03080188.2020.1730470

Woolley, J. D., Bunce, L., Boerger, E. A., (2020). Creativity and the Wandering Mind. Cambridge: Academic Press. https://doi.org/10.1016/B978-0-12816400-6.00008-0 